\title{
Analysis of the Height of Lingual Vallates Papillae in Brazilian Individuals
}

\author{
Análisis de la Altura de las Papilas Valadas Linguales en Individuos Brasileños \\ "Emanuelle Ribeiro de Oliveira; "*Marleyne José Afonso Accioly Lins Amorim; ${ }^{* *}$ Fabrício Bezerra de Sá; ${ }^{* * * *}$ Romildo de \\ Albuquerque Nogueira; ${ }^{* * * *}$ Adelmar Afonso de Amorim Júnior; ${ }^{* * * * * * *}$ Bruno Martins Araújo; \\ *******Humberto Fernandes Veloso Neto \& ${ }^{* * * * *}$ Roberto José Vieira de Mello
}

OLIVEIRA, E. R.; AMORIM, M. J. A. A. L.; SÁ, F. B.; NOGUEIRA, R. A.; AMORIM JR., A. A.; ARAÚJO, B. M.; VELOSO NETO, H. F. \& DE MELLO, R. J. V. Analysis of the height of lingual vallates papillae in brazilian individuals. Int. J. Morphol., 24(1):39-42, 2005.

SUMMARY: The vallates papillae lingual are located in the surface of the tongue in a area denominated of V lingual and it presents cells gustatory gathered in gustatory buttons. This research evaluated the height papilar in relation to the surface of the tongue of 519 lingual vallates papillae. 45 human tongue samples were selected, of both sexes, inside of the 40-50 year-old age group, obtained from necropsias accomplished in the Service of Verification of Deaths (S.V.O.) of UFPE/Secretaria of Health of the state of Pernambuco, in the city of Recife. The samples were classified different height levels accordingly in relation to the surface of the tongue, not establishing the exact height, where there was the predominance of the height above the lingual surface.

KEY WORDS: Vallates papillae; Tongue; Anatomy.

\section{INTRODUCTION}

The tongue is the main sensorial organ of the palate. It is a structure that contain different types tactile and quimiosensorial cells (Temple et al., 2002). In the surface of the tongue can be noted structures called lingual papillae, in which there are gustatory cells. Inside the oral cavity the gustatory papillae can realize the quimioreception through the contact with the saliva and other dissolved particles (Douglas, 2002). The gustatory papillae are projections of the lingual epithelium, in which there are morphological modifications of the mucous membrane that permit to increase the contact area between the tongue and the content of the mouth (Williams et al., 1995).

The vallate papillae are the greatest gustatory papillae and collect saliva from epithelium to the terminal furrows (Yasuda \& Tomita, 2002). In general, the gustatory papillae are defined as protuberances in the surface of the tongue (Bullock et al., 1991; Snell, 1999), but, particularly, the vallates papillae are described to be on the same level of the lingual surface (Avery, 2001; Katchburian \& Arana, 1999). Bhaskar (1989); Katchburian \& Arana confirmed that these papillae, really, are not salient in relation to the lingual surface. Besides, this author showed that these papillae are involved for a deep circular furrow. On the other hands, Gartner and Hiatt (1999) described the occurrence of vallates papillae submerged on the surface of the tongue.

Jeppsson (1969) declared that the vallates papillae is composed of a separate central papillae for a furrow of the surrounding wall and it increased the occurrence of individual variations with regard to the number of these papillae, size and form.

Are the papillae vallates in same plane, above or submerged in the lingual surface? This is a very interesting question that we will try answer in this paper.

\footnotetext{
Prof. of the Department of Social Medicine of the Center of Health of the Federal University of Pernambuco /Recife/ Brazil.

* Prof. Doctor of the Department of Morphology and Animal Physiology, Area of Anatomy of the Rural Federal University of Pernambuco/Recife/Brazil.

**** Prof. Doctor of the Anatomy of the Center of Biological Sciences of the Federal University of Pernambuco/Recife/Brazil.

**** Prof. Doctor of the Area of Pharmacology of the Department of Morphology and Animal Physiology of the Rural Federal University of Pernambuco/Recife/Brazil.

****** Prof. Doctor of the Department of Pathological Anatomy of the Center of Sciences of the Health of the Federal University of Pernambuco/Recide/Brazil.

${ }^{* * * * * * *}$ Monitors of Anatomy of the Department of Morphology and Animal Physiology of the Rural Federal University of Pernambuco/Recife/Brazil.
} 


\section{MATERIAL AND METHOD}

519 lingual vallates papillae were removed of 45 human tongues obtained after the realization of necropsies in cadavers of both sexes and with ages between 40-50 years old, in the Service of Verification of Obits (SVO) of the Federal University of Pernambuco (UFPE), Brazil.

All the vallates papillae were removed of the area of the $\mathrm{V}$ lingual of cadavers autopsied until 24 hours after the obit. After the collect and wash for removal of the adherent debris, the material was submitted to the fixation in $10 \%$ formaldehyde and stored to room temperature, in glass container, for a minimum period of 24 hours.

The vallates papillae were classified in accordance with the height papillary in relation to lingual surface in three groups: A. Height papillary above of the lingual surface; B. Height papillary in the same level of the lingual surface; C. Height papillary bellow of the lingual surface.

\section{RESULT}

The Figure 1 shows the photographies of the vallates papillae of the three groups. In first photography can be observed that the vallates papillae are projected in relation of the lingual surface (Group A). The second and third photographies disclose, respectively, vallates papillae on the same level (Group B) and bellow (Group C) of the lingual surface.

The distribution of the lingual vallates papillae heights in the three groups, was the following: $459(88.4 \%)$ had a height papillary above of the lingual surface (Group A); in $49(9.4 \%)$ the height papillary was in same level of the lingual surface (Group B) and in only 11 (2.1\%) the height papillary was bellow of the lingual surface (Group C).

\section{DISCUSSION}

The results found in this work showed that the vallates papillae are, in $88.4 \%$ of the cases studied, were situated above of the lingual surface. These results are contrary that of Bhaskar, Avery and Katchburian \& Arana suggested that the vallates papillae lacated in the same level or below in relation to lingual surface. Already being rare the vallates papillae lingual below the level epitelial. This lowers frequency contradicts the opinion of Gartner \& Hiatt when they referred that the vallates papillae is submerged in the surface of the tongue.

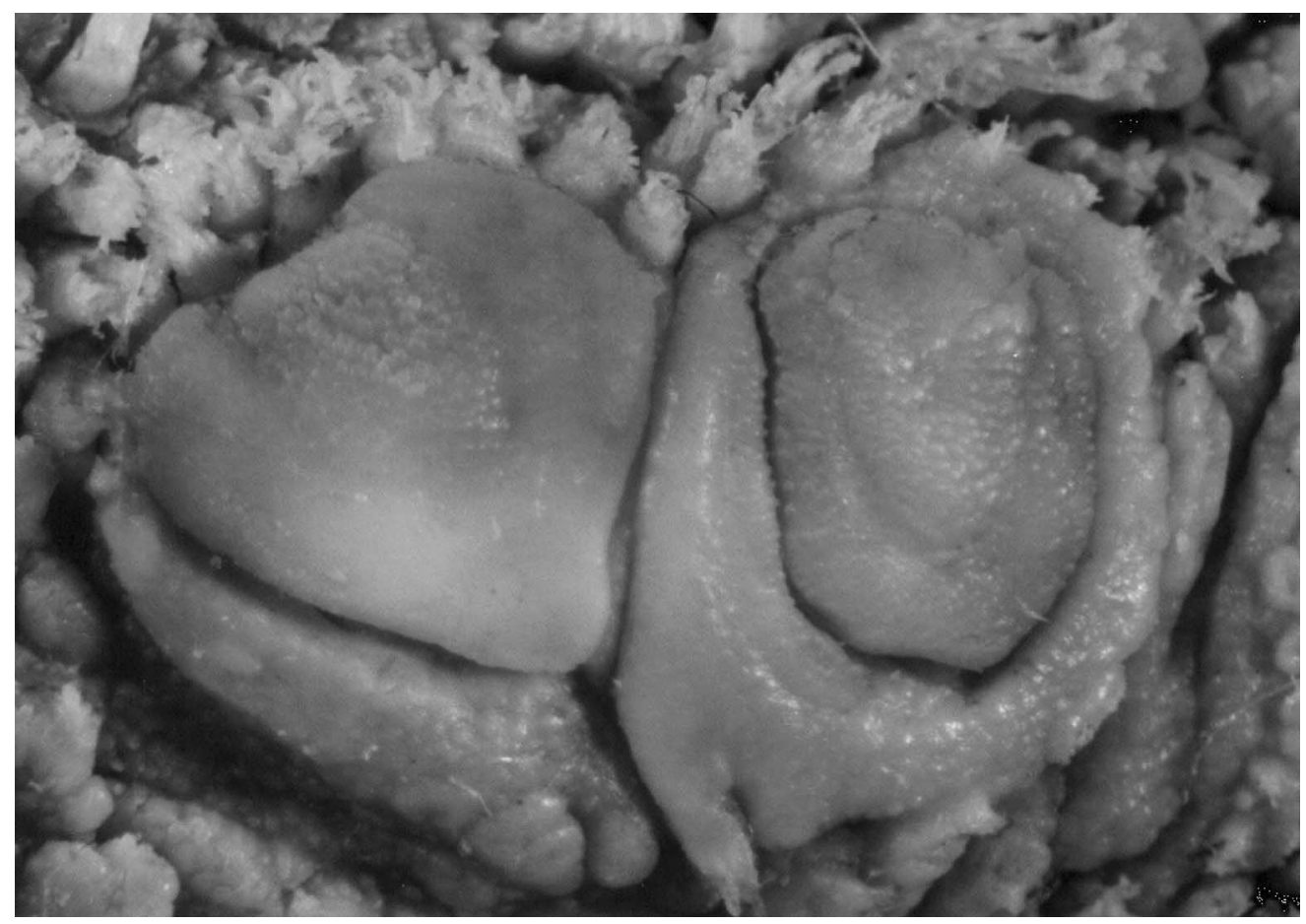

Fig. 1. Vallate papillae lingual located above the lingual surface. 100X. 


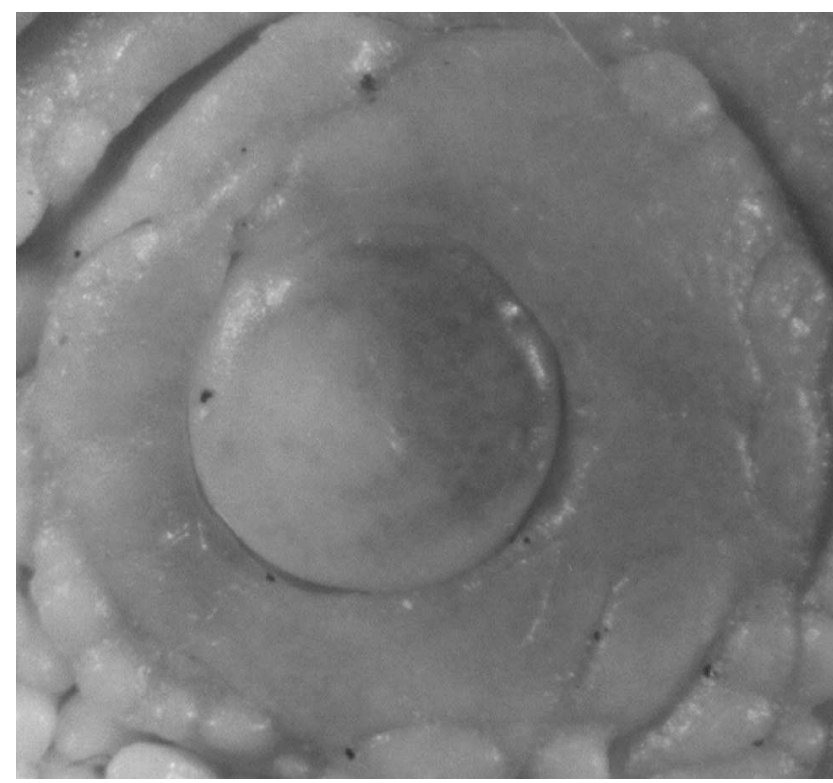

Fig. 2. Vallate papillae lingual located in same level of the lingual surface. $100 \mathrm{X}$.

The establishment of the height papilar above the lingual surface increases the area of contact of the mucous membrane papilar with the content of the oral cavity (Williams et al. and Yasuda \& Tomita), where the probability of having contact with the saliva and their dissolved particles is very larger (Douglas, 2002).

We didn't find authors mentioning the vallates papillae above the level of the lingual surface. The comments were just in relation to the lingual papilae in general if they stand out above the epithelium, but not referring from a specific way to the height of the vallates papillae (maybe for seeming logical). The height of the vallates papillae lingual has been little study object, analysis or comment, as we could observe in the reviewed literature. In general the goods stop to detail the microscopic part of the papillae lingual vallates

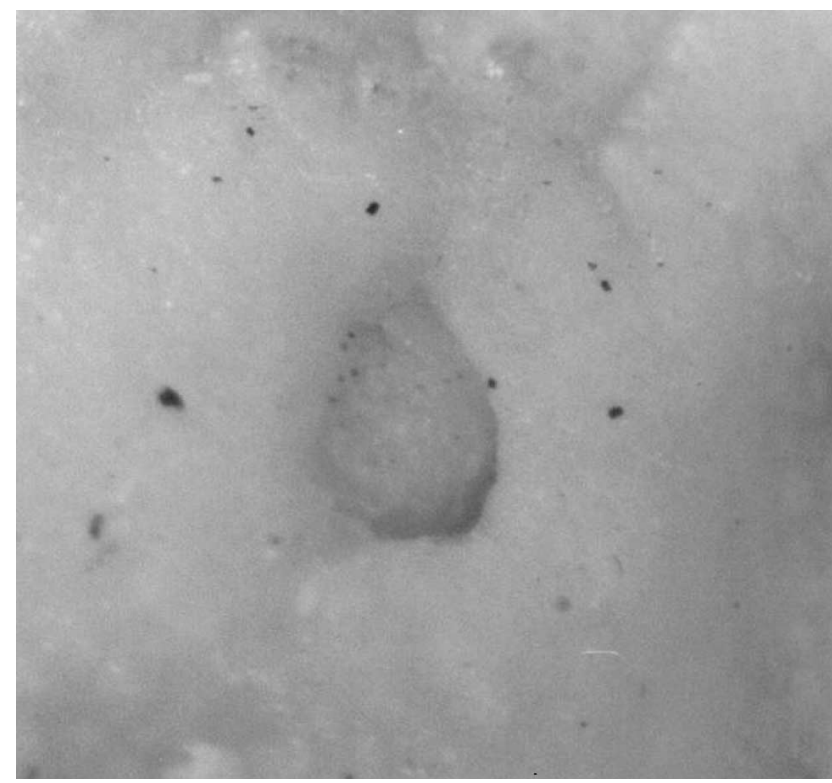

Fig. 3. Vallate papillae lingual located in bellow the lingual surface. $125 \mathrm{X}$.

more thoroughly, making little mention to the macroscopic part.

In this last case, the form parameters and of the number of these papillae, as well as of his/her location in front of the lingual $\mathrm{V}$ are the macroscopic characters more approached. Regarding the size (no specifically the height), they just mention that such papillae can vary, but that externally present the same characteristics and they are composed of a separate central papillae for a furrow of the surrounding wall (Jeppsson).

Are the papillae vallates in same plane, above or submerged in the lingual surface? Now is possible to answer that the vallates papillae in Brazilian individuals are in $88.4 \%$ of the cases studied above of the tongue surface.

OLIVEIRA, E. R.; AMORIM, M. J. A. A. L.; SÁ, F. B.; NOGUEIRA, R. A.; AMORIM JR., A. A.; ARAÚJO, B. M.; VELOSO

NETO, H. F. \& DE MELLO, R. J. V. Análisis de la altura de las papilas valadas linguales en individuos brasileños. Int. J. Morphol., 24(1):39-42, 2006.

RESUMEN: Las papilas valadas linguales están localizadas en la superficie dorsal de la lengua, en un área denominada V lingual y presentan células gustativas acumuladas en botones gustativos. Se evaluó la altura papilar en relación con la superficie de la lengua de 519 papilas valadas linguales. Fueron seleccionadas 45 lenguas humanas, de individuos de ambos sexos, de 45 a 50 años de edad, obtenidas de autopsias del Servicio de Verificación de Óbitos de la Universidade Federal ed Pernambuco /Secretaría de Salud del Estado de Pernambuco, Recife, Brasil. Las muestras fueron clasificadas de acuerdo a los niveles de altura en relación con la superficie de la lengua, no estableciéndose la altura exacta, donde hubo predominio de papilas ubicadas sobre la superficie lingual.

PALABRAS CLAVE: Papilas valadas; Lengua; Anatomía. 
OLIVEIRA, E. R.; AMORIM, M. J. A. A. L.; SÁ, F. B.; NOGUEIRA, R. A.; AMORIM JR., A. A.; ARAÚJO, B. M.; VELOSO NETO, H. F. \& DE MELLO, R. J. V.

\section{REFERENCES}

Avery, J. K. Fundamentos de Histologia e Embriologia Bucal. $2^{\mathrm{a}}$. ed. Rio de Janeiro, Guanabara Koogan, 2001.

Bhaskar, S. N. Histologia e Embriologia Oral de Orban. 10ª ed. São Paulo, Artes Médicas, 1989.

Bullock, J.; Boyle, J., III \& Wang, M. B. Physiology. 2a . ed. Pennsylvania, Williams \& Wilkins, 1991.

Douglas, C. R. Tratado de Fisiologia Aplicada à Saúde. $5^{\mathrm{a}}$. ed. São Paulo, Robe, 2002.

Gartner, L. P. \& Hiatt, J. L. Tratado de Histologia. Rio de Janeiro, Guanabara Koogan, 1999.

Jeppsson, P. H. Studies on the structures an innervation of taste buds. An experimental and clinical investigation. Acta Otolaryngol., 259 (Suppl. 1):16-95,1969.
Katchburian, E. \& Arana, V. Histologia e Embriologia Oral. Rio de Janeiro, Guanabara Koogan/Panamericana, 1999.

Snell, R. S. Anatomia Clínica para Estudantes de Medicina. 5 . ed. Rio de Janeiro, Guanabara Koogan, 1999.

Temple, E. C.; Hutchinson, I.; Laing, D. G. \& Jinks, A. L. Taste development: differential growth rates of tongue regions in humans. Dev. Brain Res., 135(1-2):65-70, 2002.

Williams, P. L.; Warnick, R.; Dyson, M. \& Bannister, L. H. Gray Anatomia. 37 . ed. Rio de Janeiro, Guanabara Koogan, 1995.

Yasuda, M. \& Tomita, H. Electron Microscopic Observations of Glossal Circumvallate Papillae in Dysgeusic Patients. Acta Otolaryngol., 546(Suppl.1):122-8, 2002.

Dirección para correspodencia:

Prof. Dra. Marleyne Jose Afonso Accioly Lins Amorim

Universidade Federal Rural de Pernambuco

Departamento de Morfologia e Fisiologia Animal

Rua Dom Manuel de Medeiros, $S / \mathcal{N}$ Dois Irmãos

Recife- $P E$

BRASIL

Email:mjaamorim@yahoo.com.6r

slothvariegatus@fotmail.com

Received: 04-02-2005

Accepted: 12-12-2005 